\title{
Kütanöz inflamasyon
}

\section{Özet}

Inflamasyon konağın mikroorganizmalar, zedelenmiş hücreler, fiziksel ve kimyasal irritanlar gibi zararlı uyaranlara karşı verdiği koruyucu bir yanıttır. Dokudaki vasküler yapı, immün sistem ve çeşitli hücrelerin katıldığı bir dizi biyokimyasal olaylar inflamasyonu başlatır ve olgunlaştııır. inflamasyon akut veya kronik olarak olabilir. Akut inflamasyon zararlı uyaranlara karşı ilk oluşan yanıttır, plazma ve lökositlerin dokuya artmış akımı ile karakterizedir. Akut inflamasyonun klasik bulguları ağıı, ısı artışı, kızarıklık, şş̧lik ve fonksiyon kaybıdır. Süreç uzadığında kronik inflamasyon olarak adlandırıır ve bu bölgedeki hücrelerin progresif değişimi ile eşzamanlı olarak dokuda yıkım ve iyileşme süreci ile karakterizedir. Dokunun ve zedeleyici ajanın özellikleri inflamasyonun iyileşme, fibrozis veya kronikleşme şeklinde olabilen sonucunu belirlemektedir. Uygun olmayan inflamasyon kronik inflamatuvar hastalıklarda dokuların yıkımına yol açabilir. (Türkderm 2013; 47: Özel Sayı 1: 28-36)

Anahtar Kelime: Inflamasyon, tamir, rejenerasyon, aracı maddeler

\section{Summary}

Inflammation is a protective response of the host to harmful stimuli, such as microorganisms, damaged cells, chemical and physical irritants. A cascade of biochemical events propagates and matures the inflammatory response, involving the local vascular system, the immune system, and various cells within the injured tissue. Inflammation can be classified as either acute or chronic. Acute inflammation is the initial response of the body to harmful stimuli and is achieved by the increased movement of plasma and leukocytes. The classical signs of acute inflammation are pain, heat, redness, swelling, and loss of function. Prolonged inflammation, known as chronic inflammation, leads to a progressive shift in the type of cells present at the site of inflammation and is characterized by simultaneous destruction and healing of the tissue. Characteristics of the tissue and the injurious agent determine the outcome of inflammation, such as healing, fibrosis and leading to chronic inflammation. Inappropriate inflammation can lead to destruction of tissues in chronic inflammatory disorders. (Turkderm 2013; 47: Suppl 1: 28-36)

Key Words: Inflammation, repair, regeneration, mediators

\section{Giriş}

Inflamasyon; mikroorganizmaların veya toksinlerin hücrelere zarar vermesinin önlenmesi ya da hasar sonucu oluşan nekrotik ve ölü dokuların uzaklaştııımasına yönelik, organizmanın devamlılığı için geliştirilmiş koruyucu bir yanıttır. İnflamasyon kan damarları ve ı̈̈kositlerin önemli rol oynadığı karmaşık bir olaydır. İnflamasyonun vasküler ve sellüler reaksiyonları, çeşitli hücreler tarafından üretilen veya bazı plazma proteinlerinden kaynaklanan mediatörler tarafından başlatılmaktadır. Mikroorganizmalar, toksinler, nekrotik hücreler, mekanik ve kimyasal ajanlar ve hatta hipoksik durum bile inflamatuvar mediatörler- in salınıp inflamasyonun başlamasına sebep olabilir2. Normal şartlar altında yanıtın sıkı kontrol edilmesi daha fazla hasar oluşmasını önler ve hasarlı dokular temizlenirken, hastalık durumlarında oluşan patolojik inflamasyon ekstrasellüler matrix harabiyetine ve organ disfonksiyonuna neden olmaktadır. Inflamasyon; uyaranın özelliğine, ilk uyaranı elimine etme konusunda oluşturulan yanıtın yeterliliğine ve oluşan doku hasarına bağlı olarak akut ve kronik olabilir. Akut inflamasyon hızlı başlar, süresi kısadır (birkaç saat- birkaç gün), önemli özelliği ödem ve lökositlerden zengin doku infiltrasyonudur. Akut inflamasyonda ilgili ajan uzaklaştırilınca olay sona ererken yanıtın yeterli olmadığı durumlarda kronik faza

Yazışma Adresi/Address for Correspondence: Dr. Nilgün Şentürk, Ondokuz Mayıs Üniversitesi Tıp Fakültesi Deri ve Zührevi Hastalıklar Anabilim Dalı, Samsun, Türkiye Gsm.: +905392114480 E-posta: nilsenturk@yahoo.com

Türkderm-Deri Hastalıkları ve Frengi Arșivi Dergisi, Galenos Yayınevi tarafından basılmıștır.

Turkderm-Archives of the Turkish Dermatology and Venerology, published by Galenos Publishing. 
ilerleyebilir3. Kronik inflamasyon akut inflamasyonu takip edebilir ya da sinsice başlayabilir. Süresi daha uzundur, dokularda lenfosit ve makrofaj hakimiyeti, vasküler proliferasyon, fibrozis ve doku yıkımı ile karakterizedir ${ }^{3}$. Inflamatuvar yanıt; ilgili ajan ortamdan uzaklaştırıldı̆ında sonlanır ama bu süreç onarımla iç içedir. Olay devam ederken onarım süreci de başlar fakat etken tamamen uzaklaştırılıktan sonra parenkimal ve bağ dokusu elemanlarının rejenarasyonu ile tamamlanır. Bazı durumlarda inflamasyon zarar verebilir, vücuda zararlı etkenleri uzaklaştırmaya yönelik olarak geliştirilen mekanizma normal dokuları da zedeleyebilir. Inflamasyonun kişinin kendi dokularına karşı geliştiği veya yeterince kontrol edilemediği durumlarda da bazı hastalıklar ortaya çıkabilmektedir. Dermatolojide sellülit, erizipel, böcek ısırığı gibi bir çok durumda, inflamatuvar yanıt, etkeni hızlı ve etkili bir şekilde yok ederken; psoriasis, Behçet hastalığı gibi durumlarda etkenin belirlenemediği kronik, kontrolsüz inflamatuvar yanıt söz konusudur.

\section{Tarihçe}

Inflamasyonun klinik özellikleri Celsus tarafından i.Ö. 3000 li yıllarda eski Mısır papirüslerinde rubor (eritem), tumor (ödem) calor (ısı artışı) ve dolor (ağrı) şeklinde tanımlanmıştır. Bu bulgular tipik olarak akut enflamasyonda daha belirgindir. Beşinci bulgu olarak fonksiyon kaybı ise Rudolf Virchow tarafından 19 yüzyılda eklenmiştir³. 1793 de İskoç cerrah John Hunter, inflamasyonun bir hastalık olmadığını nonspesifik bir yanıt olduğunu öne sürmüştür. Derideki inflamasyon üzerinde çalışan Thomas Lewis ise histaminin enflamasyondaki vasküler değişikliklere aracılık ettiğini öne sürmüştür. Bu kavram inflamasyonda kimyasal mediatörlerin önemine dikkat çekmiş ve antiinflamatuvar ajanların bu alanlarda kullanılmasına neden olmuştur ${ }^{3}$.

Akut inflamasyon

Akut inflamasyon konağın ani yanıtı ile ortaya çıkar, enfeksiyon yada zedelenme bölgesine lökosit ve plazma proteinlerin hızlı ulaşması ile karakterizedir. Akut inflamasyonun üç önemli bileşeni vardır:

1) Kan akımında artışa neden olan vasküler çap artışı

2) Plazma proteinleri ve lökositlerin dolaşımı terk etmesine neden olan mikrovasküler alanda yapısal değişiklikler

3) Lökositlerin mikrodolaşımı terk edip zedelenme bölgesinde toplanması ve ajanı yok etmek için aktive olmaları3.

Enfeksiyonlar (bakteriyel, viral, fungal, paraziter); Toll benzeri reseptörler (TLR) ve bazı sitoplazmik reseptörler aracılığı ile çeşitli mediatörlerin salınımını indükleyerek inflamatuvar yanıtı başlatırlar. İskemi, travma, fiziksel ve kimyasal zedelenme sonucu ortaya çıkan doku nekrozu, ürik asit, ATP, HMGB-1 (fonksiyonu bilinmeyen DNA bağlayıcı protein) aracılığı ile reaksiyonu başlatırken, ortama salınan DNA, hipoksi ve yabancı cisimlerin (kıymık, kir, sütur artıkları) yanısıra immun reaksiyonlar da inflamasyonu tetikleyebilmektedir. Normalde korumaya yönelik olarak gelişen bu immun reaksiyonlar kişinin kendi dokularına da zarar verebilmektedir. Immunolojik reaksiyon kişinin kendi dokularına yönelikse otoimmun hastalıklar ortaya çıkar. Bazen de çevresel uyaranlara karşı aşırı yanıt şeklinde kendini gösterebilir (hipersensitivite reaksiyonları). T lenfositler ve immun sistemin diğer hücrelerinden kaynaklanan sitokinler aracılığı ile oluşturulan inflamasyon sonucu ortaya çıkan hastalıklar, immun-aracılı inflamatuvar hastalıklar olarak adlandırımaktadır. Inflamasyonu ortaya çıkaran uyaranın tipi, şiddeti, etkilenen dokunun özelliği ve kişinin verdiği yanıta bağlı olarak akut enflamasyon ya tamamen geriler, ya bağ dokusu rejenerasyonu ile iyileşir ya da kronik inflamasyona ilerler.

\section{Kronik inflamasyon}

Kronik inflamasyon; inflamasyon, doku hasarı ve onarım sürecinin iç içe olduğu uzun bir süreçtir. Ya akut inflamasyonu izler ya da akut inflamasyon bulguları olmadan sinsice başlayabilir. Persistan enfeksiyonlar (mikobakteri, bazı virüs ve parazitler), immun aracılı inflamatuvar hastalıklar, potansiyel toksik ajanlara kronik maruziyet (silika gibi) kronik inflamasyona neden olabilir. Vasküler değişiklikler, ödem ve nötrofilik infiltrasyonla karakterize akut inflamasyonun aksine kronik inflamasyonda makrofaj, lenfosit ve plazma hücrelerinden zengin mononükleer hücre infiltrasyonu izlenir. Bunun yanı sıra doku yıkımı ve bunun bağ dokusu rejenerasyonu ile onarımı belirgindir.

\section{Inflamasyonun sistemik etkileri}

Inflamatuvar uyarılarla artan sitokinler özellikle akut inflamasyon durumlarında sistemik bulgulara neden olabilir. Bu akut faz yanıtı ateş, akut faz proteinlerinde artış ( CRP, fibrinojen, serum amiloid A proteini vs), lökositoz gibi bazı klinik ve patolojik değişiklikleri içermektedir.

\section{İnflamatuvar yanıtın başlaması ve inflamazom}

Normal bir doku patojenle karşılaştığı zaman buradaki yerleşik hücrelerin biçem tanıma reseptörleri patojen ajanla bağlanması sonucu aktive olarak doğal immun yanıtı harekete geçirir. Doğal immun sistemin hücreleri konak savunmasında erken dönemdeki olayları düzenlemenin yanı sıra, dentritik hücreler aracılığı ile adaptif immun sistemi de devreye sokarlar4

Tehlike sinyallerini ve potansiyel patojenleri algılayan reseptörler hücrenin stoplazmasında bulunur. Bunlar içinde inflamazomlar en iyi tanımlanan sistemlerden birisidir ve insan NOD-benzeri -reseptör (NLR) ailesinin 22 üyesini içerir. Aktive olan NLR proteinleri diğer proteinleri de bu bölgeye toplayarak Caspaz-1 ve adaptör molekül apoptosisilişkili specklike protein (ASC) ile bir kompleks oluşturur. Caspaz-1 in aktive olması inflamazomların en önemli fonksiyonlarından birisidir ve IL-1, IL-18, ve IL-33 ün klevajı ve aktivasyonu ile sonuçlanır ${ }^{5}$. Inflamazomun bozuklukları otoinflamatuvar hastalıklara neden olmaktadır. Bunun prototipik örneği kriyopirini kodlayan (NALP3 olarak da bilinen) NLR genindeki mutasyonlara bağlı olarak ortaya çıkan familial soğuk otoinflamatuvar hastalık, Muckle-Wells hastalığı ve neonatal başlangıçlı multisistem inflamatuvar hastalıktır (NOMID). Bu üç nadir görülen hastalık anormal inflamazom aktivasyonu ve IL-1 $\beta$ nın uygunsuz salınımı ile ilgidir6.

Doku hasarını takiben oluşan inflamatuvar yanıt ile mikrovasküler hasar, lökosit ekstravazasyonu oluşur ve plazma ve proteinleri dokuya sızar. Bazı durumlarda inflamazom bunu algılayarak olayı başlatma rolü oynarken; iskemi gibi durumlarda, asit sensitif iyon kanalları doku pH'sının azalmasını algılayarak çevresel tehlikeyi tespit eder. Vasküler hasar alanındaki trombüs formasyonu, vazoaktif aminler (serotonin), lizozomal proteazlar ve eykozanoid ürünlerinin oluşumu inflamatuvar kaskadı başlatır. Trombositler daha sonra da PDGF ve TGF $\beta$ gibi büyüme faktörlerinin salınması ile iyileşme sürecini de regüle etmektedir?

\section{Inflamatuvar yanıtın ikinci aşaması}

Doğal immun sistemin aktivasyonu bu bölgeye hızla inflamatuvar hücrelerin gelmesini sağlar. Vasküler endotel hücreleri, mast hücreleri, dendritik hücreler ve interstisiyal fibroblastlar gibi yerleşik hücreler, eykozonoidler ve pro-inflamatuvar sitokinlerin salııımı ile bu olaya yanıt verirler (Tablo 1)4. Bu mediatörler inflamatuvar yanıtı arttırarak daha fazla lökositin bu bölgeye gelmesini sağlarlar. Lokal olarak uyarılan hücreler ve yeni gelenler, toksik reaktif nitrojen ve oksijen ara ürünleri 
ile matrix metalloproteinazlar (MMPs), serin ve sistein proteazlar gibi çeşitli proteazların salınmasına neden olurlar. Bu moleküller enfeksiyon ajanlarını yok eder ve zedelenen dokuların uzaklaştııımasını sağlayarak zedelenme bölgesini tamir için temizlerler. Akut inflamatuvar mekanizmaların uyarımasının uzaması ciddi doku hasarına neden olur. Normal fizyolojik yanıt ise doku hasarından ziyade, proteolitik enzimlerle ekstrasellüler matriksin (ECM) yeniden şekillenmesi ve yara iyileşmesi için gerekli destek dokuların oluşmasını sağlar2,3.

Tablo 1. Inflamasyonun başlaması ve onarımda rol oynayan sinyaller

\begin{tabular}{|c|c|}
\hline İnflamasyon & Onarım ve doku tamiri \\
\hline \multicolumn{2}{|c|}{ Sitokinler ve büyüme faktörleri } \\
\hline TNF & TGF- $\beta$ \\
\hline IL-1 ailesi (IL-1, IL-18, IL-33) & IL-10 \\
\hline $\begin{array}{l}\text { IL-6 ailesi (IL-6, IL-11, LIF, } \\
\text { osteopontin) }\end{array}$ & FGF \\
\hline IL-4, IL-13 & Osteoprotegerin \\
\hline IL-15 & $\| \mathrm{IL}-1 \mathrm{RI}$ \\
\hline IL-17 ailesi (IL-17A-F) & IL-1 Ra \\
\hline IL-12 ailesi (IL-12, IL-23, IL-27) & Soluble TNF-R \\
\hline VEGF & IL-18 bağlayıcı protein \\
\hline \multicolumn{2}{|l|}{ Kemokinler } \\
\hline \multicolumn{2}{|l|}{ Proteazlar } \\
\hline $\begin{array}{l}\text { Matrix metalloproteinazları } \\
\text { (MMPs) }\end{array}$ & TIMPS \\
\hline \multicolumn{2}{|l|}{ Kollajenazlar } \\
\hline \multicolumn{2}{|l|}{ Jelatinazlar } \\
\hline \multicolumn{2}{|l|}{ Stromelizinler } \\
\hline \multicolumn{2}{|l|}{ Matrilizinler } \\
\hline Serin proteazlar & SERPINs, $\alpha 2$-makroglobulin \\
\hline \multicolumn{2}{|l|}{ Tripsin } \\
\hline \multicolumn{2}{|l|}{ Kimotripsin } \\
\hline \multicolumn{2}{|l|}{ Sistein proteazlar } \\
\hline \multicolumn{2}{|l|}{ ADAMTS ailesi } \\
\hline \multicolumn{2}{|l|}{ Aggrekanazlar } \\
\hline \multicolumn{2}{|l|}{ Küçük moleküllü mediatörler } \\
\hline Prostaglandinler $\left(\mathrm{PGE}_{2}\right)$ & Lipoksinler \\
\hline Leukotrienler (LTB4) & Siklopentenon \\
\hline C3a ve $\mathrm{C5a}$ & Antioksidanlar \\
\hline \multicolumn{2}{|l|}{ Histamin } \\
\hline \multicolumn{2}{|l|}{ Bradikinin } \\
\hline \multicolumn{2}{|l|}{ Reaktif oxijen } \\
\hline \multicolumn{2}{|l|}{ Reaktif nitrojen } \\
\hline \multicolumn{2}{|l|}{ Apoptozis mediatörleri } \\
\hline \multirow[t]{4}{*}{ Soluble Fas ligand } & Fas \\
\hline & TRAIL \\
\hline & Reaktif oxygen \\
\hline & Reaktif nitrogen \\
\hline
\end{tabular}

\section{Hücresel yanıt ve adezyon molekülleri}

Doku hasarının olduğu bölgedeki inflamatuvar hücre infiltrasyonu bir düzen içinde gelişir. Süreç insterstisiyel fibroblastlar, mast hücreleri ve vasküler endoteliyal hücreler gibi yerleşik hücrelerden kemokinlerin ve soluble mediatörlerin salınımı ile başlar. Bunların oluşturduğu sinyaller lokal adezyon molekülü profilini değiştirerek kemotaktik gradient oluşturur ve dolaşımdan dokulara hücre geçişini sağlar. Özellikle mast hücreleri bu süreçte çok önemli rol oynarlar ve saniyeler içinde içerdikleri vazoaktif aminleri salarlar. Birçok akut yanıtta, polimorfonükleer (PMN) lökositler dolaşımı ilk terk edip zedelenme bölgesine ulaşan hücrelerdir, daha sonra bunu farklı sinyallerin etkisiyle hareket eden mononükleer hücreler izler8,9. Doku fibroblastları ve vasküler endotelial hücreler PMN'lerin dokuya gelmesinden önce sessizken, uyarıldıktan sonra prolifere olarak zedelenme bölgesine göç ederler, aynı zamanda çeşitli sitokin, proteazlar ve ECM komponentlerini sentezlerler. Salınan, basic fibroblast büyüme faktörü (bFGF) ve vasküler endoteliyal büyüme faktörü (VEGF) gibi büyüme faktörleri yeni damar oluşumunu uyarır. Granulosit-makrofaj koloni-stimule edici faktör (GM-CSF) ile birlikte lokal olarak salınan büyüme faktörleri, hücresel proliferasyon ve inflamatuvar yanıtın amplifikasyonuna katkıda bulunur, ve antijen sunumunda önemli rol oynayan dentritik hücrelerin maturasyonunu indükler. Fibroblastlar ve endotelial hücreler yeni ECM proteinleri, MMPs ve diğer ECM sindirici enzimleri de sentezlerler. Proteaz ve ECM üretimi arasındaki denge inflamasyon süresince doku remodelize olurken değişiklik göstermektedir. Başlarda yanıt, hasarlanmış yapıları uzaklaştırmak için proteolitik aktivite yönündedir. Bu süreç daha sonra tamir ve yara iyileşmesini sağlamak amac ile yeni ECM üretimine kayar10. Endotelial tight-junctionların bozulması ile artan vasküler permeabilite fibrinojen, fibronektin, ve vitronektin gibi plazma kaynaklı proteinlerin perivasküler ECM'e sızmasına neden olur. Bunların ECM ile etkileşimi adezyon molekülleri için (e.g., integrinler $\alpha 5 \beta 1$ ve $\alpha v \beta 3$ ) yeni ligand oluşumuna neden olur. Artan vasküler permeabilite ve adezyon molekülü-ligand profilindeki değişiklikler, ve kemoatraktan moleküllerin salınımı lökositlerin inflamasyon bölgesinde toplanmasını arttıır. Burada rol oynayan bazı kemokinlerden; IL-8 nötrofiller için, makrofaj kemoatraktan protein-1 (MCP-1) monositler için, RANTES (regulated on activation, T-cell expressed and secreted) monosit ve eozinofil için, IL-6 ise CD4+ T hücreleri için kemoatraktandır ${ }^{11}$.

Inflamatuvar lezyonlarda bulunan kemokin ve vasküler adezyon moleküllerinin kombinasyonu, zamanın spesifitesini ve toplanacak inflamatuvar hücre alt tiplerini belirler. Integrinlerin lökositlere bağlanması da dokuya gittiklerinde apoptozisi önleyerek bunların yaşamlarını uzatır. Bazı spesifik adezyon molekülü-ligand çiftlerinin ekspresyonu bazı hastalıklarda önemli rol oynamaktadır, örneğin $\alpha 5$ integrin ve bunun ligandı olan fibronektinin psoriasis gelişiminde rol oynadığı gösterilmiştir12

\section{Soluble Mediyatörler (Tablo 2).}

\section{Pro-inflammatuvar sitokinler}

Genellikle makrofaj ve fibroblastlardan köken alan pro-inflammatuvar sitokinler, immun sistemi aktive eden mediyatörlerdir. IL-1 ailesinin proinflamatuvar üyeleri (IL- $\alpha, \mathrm{IL}-1 \beta, \mathrm{IL}-18$, and IL-33) ve TNF'nin farklı yönde etkileri vardır. Endoteliyal hücrelerde adezyon molekül ekspresyonunu arttırıp proliferasyonunu indükler ve antijen sunumunu uyarırlar. IL-1 ve TNF aynı zamanda matrix yıkımını sağlayan kollajenaz ve stromelisin gibi enzimlerin ekspresyonunu arttırır ve fibroblastlardan 
prostaglandin E 2 (PGE 2) gibi diğer inflamatuvar mediatörlerin sentezini uyarır. TNF inhibitörleri psoriasis, romatoid artrit ve inflamatuvar barsak hastalığı gibi inflamatuvar hastalıklarda, IL-1 inhibitörleri de ailesel soğuk otoinflamatuvar hastalık ve Muckle-Wells sendromu gibi genetik hastalıklarda etkili tedavi yöntemleridir. IL-1 ve TNF akut sitokin yanıtının sadece küçük bir kısmını oluşturur. Hem akut faz reaktanlarını indükleyen hem de TH1 veya TH2 yönünde immun yanıtı farklılaştıran IL-6 ve ilgili sitokinler (IL-11, osteopontin) gibi farklı diğer faktörler de olaya katılmaktadır (Şekil 1)2,13

GM-CSF dentritik hücre maturasyonunu regüle eder, bu hücreler üzerinde HLA-DR ekspresyonunu ve antijen sunumunu arttırır. TH1 lenfokin olan IFN- $\gamma$, HLA-DR ekspresyonunu ve endotel hücre adezyon moleküllerinin ekspresyonunu arttırıken kollejen üretimini baskılar2 IL-1, IL-6 ve IL-23; ürettiği IL-17 ailesinin ürünleri sayesinde (IL-17 A-F) inflamasyon ve otoimmunitede Th17 yönündeki farklılaşmayı koordine eder. Bunlar arasında özellikle IL-17 A ve belki de IL-17F, IL-1 ve TNF ile gösterdikleri sinerji nedeni ile önemlidir ${ }^{14}$. Büyüme faktörü olan TGF- $\beta$, hücreleri regülatör T hücre yönünde farklılaştırır, bu da diğer $T$ hücrelerinin antijen spesifik yanıtını baskılar10. Sitokinler birçok inflamatuvar hastalığın başlamasında ve devamında önemli rol oynamaktadır. Özellikle psoriasisdeki sitokin ağı oldukça komplekstir. INF- $\gamma$, TNF- $\alpha$, çeşitli interlökinler ve kemokinler hastalığın oraya çıkmasına katkıda bulunmaktadır ${ }^{15}$.

\section{Eykosonoidler}

Lokal inflamatuvar yanıtta, sitokin ve immun komplekslerin yanı sıra lipid kökenli molekül olan eykozonoidler de salınmaktadır. Lipidler hücre membranında bulunduğu için bu mediatörlerin salınması için hazır maddelerdir. Eykozonoidler depo edilmezler, yarı ömürleri çok kısadır (saniyeler veya dakikalarla ölçülür). Hücreler; mekanik travma, sitokinler, büyüme faktörleri veya diğer uyarılara maruz kaldıklarında membran lipidlerinden araşidonik asit metabolitleri açığa çıkar. Sitozolik fosfolipaz A2 eykosonoid üretiminde önemli bir enzimdir. Hücre-spesifik ve agonist-bağımlı olaylar sitozolik fosfolipaz A2 nin, sikloksijenaz (COX, prostaglandin sentezi) ve 5-lipoksijenazla (lökotrien sentezi) etkileşime girebileceği yerler olan nükleer zara, endoplazmik retikulum ve Golgi cisimciğine taşınmasına neden olur16,17.

\section{Prostaglandinler}

Prostanoidler; fosfolipazlar tarafından, zedelenen hücrelerin mebranından salınan araşidonik asitten üretilir, sikloksijenaz ve spesifik izomerazlar tarafından metabolize edilirler (Şekil 1). Üretimleri akut inflamatuvar reaksiyonlarda artar. Eksojen ve endojen pirojenlere yanıt olarak COX2'den sentezlenen PGE2 santral febril yanıta aracilık eder. Ayrıca prostaglandinler vasküler yanıtı arttırma ve ödem oluşumunda bradikinin ve histamin ile sinerjistik çalışılar. Normal dokularda prostaglandin seviyeleri oldukça düşüktür ve akut enflamasyonla birlikte, lökosit toplanmasından önce, hızla artar. Inflamatuvar uyarı ile indüklenen COX2 kronik enflamasyonda yüksek prostanoid seviyelerinden sorumludur. COX2 aynı zamanda trombosit-endotel hücre etkileşiminde endotel hücrelerinden prostasiklin üretimini arttırarak önemli rol oynamaktadır ${ }^{16}$.

\section{Lökotrienler}

Prostaglandinlere ek olarak farklı bir enzim grubu da araşidonik asit metabolitlerini lökotrien sentezine yönlendirir. Bunların önemi inflamatuvar yanıtta hedefledikleri dokulara bağlıdır. Örneğin lökotrien

Tablo 2. Inflamasyonun soluble mediatörleri

\begin{tabular}{|c|c|c|}
\hline Mediatör & Kaynağı & Etkileri \\
\hline Sitokinler (II-1, TNF) & Mast hücreleri, makrofajlar & Endotel aktivasyonu, doku hasarı, ağrı ateş şok \\
\hline Kemokinler & Mast hücreleri, lökositler & Lökosit kemotaksisi ve aktivasyonu \\
\hline Prostaglandinler & Mast hücreleri, lökositler & Vazodiatasyon, ağrı, ateş \\
\hline Lökotrienler & Mast hücreleri, lökositler & Permeabilite artışı, lökosit adezyon ve kemotaksisi \\
\hline Histamin & Mast hücreleri, bazofiller & Vazodiatasyon, permeabilite artışı \\
\hline Serotonin & Trombositler & Vazodiatasyon, permeabilite artışı, ağrı, ateş \\
\hline Trombosit aktive edici faktör & Lökositler, mast hücreleri & Vazodiatasyon, permeabilite artışı, lökosit adezyon ve kemotaksisi \\
\hline Reaktif oksijen araürünleri & Lökositler & Mikrop öldürme, doku hasarı \\
\hline Nitrik oksit & Makrofajlar, endotel & Mikrop öldürme, düz kaslarda gevşeme \\
\hline Kompleman & Plazma & Lökosit kemotaksisi ve aktivasyonu \\
\hline Kinin & Plazma & Vazodiatasyon, permeabilite artışı, ağrı \\
\hline Proteazlar & Plazma & Lökosit toplanması \\
\hline
\end{tabular}


antagonistleri bazı ürtiker alt tiplerinde etkili olurken psoriasisde etkili değildirler. Prostaglandinlerin tersine, lökotrienler esas olarak nötrofil, makrofaj ve mast hücresi gibi inflamatuvar hücrelerden sentezlenir (Şekil 1). Bu yolda 5-lipooksijenaz anahtar rol oynar, salınan araşidonik asiti, 5-lipoksigenaz-aktive edici protein (FLAP) ile uyum içinde, epoksit lökotrien A4'e dönüştürür17. LTA 4; endotel hücrelerine lökosit yapışmasının güçlü bir nötrofil kemoatraktan ve stimülatörü olan sitosolik LTA4 hidrolaz ile LTB4'e hidrolize olabilir. LTA4'de nükleer zarf da LTC4 sentaz tarafından LTC4 oluşturmak için glutatyon ile

Tablo 3. Matriks metalloproteinazları ve substratları

\begin{tabular}{|c|c|c|}
\hline MMP ailesi & Matriks Substratları & Diğer substratlar \\
\hline \multirow[t]{2}{*}{ Kollajenazlar } & $\begin{array}{l}\text { Kollajen I, II, III, } \\
\text { VII, X }\end{array}$ & $\begin{array}{l}\text { Pro-MMP-1, }-2,-8,-9, \\
-13\end{array}$ \\
\hline & Aggrecan & Pro-TNF- $\alpha$ \\
\hline \multirow[t]{3}{*}{ Entactin } & $\begin{array}{l}\alpha_{1} \text {-Proteinaz } \\
\text { inhibitörleri }\end{array}$ & \\
\hline & Gelatin & \\
\hline & Tenascin & \\
\hline \multirow[t]{6}{*}{ Gelatinazlar } & Aggrecan & Pro-MMP-1, -2 , and -13 \\
\hline & Denature kollajen & Pro-TNF- $\alpha$ \\
\hline & Elastin & Pro-IL-1 $\beta$ \\
\hline & Fibronectin & Latent TGF- $\beta$ \\
\hline & Laminin & \\
\hline & Vitronectin & \\
\hline \multirow[t]{9}{*}{ Matrilizinler } & Proteoglikanlar & Pro-MMP-2 and -7 \\
\hline & Denature kollajen & Pro-TNF- $\alpha$ \\
\hline & Entactin & $\begin{array}{l}\text { Membrana bağlı Fas } \\
\text { ligand(FasL) }\end{array}$ \\
\hline & Fibrin, fibrinogen & \\
\hline & Fibronectin & Plasminogen \\
\hline & Gelatin & $\beta 4$ Integrin \\
\hline & Laminin & \\
\hline & Tenascin & \\
\hline & Vitronectin & \\
\hline \multirow[t]{11}{*}{ Stromelizinler } & Proteoglicanlar & $\begin{array}{l}\text { Pro-MMP-1, }-3,-7,-8, \\
-9,-10,-13\end{array}$ \\
\hline & Aggrecan & \\
\hline & $\begin{array}{l}\text { Kollajen III, IV, V, } \\
I X, X, X I\end{array}$ & Pro-TNF- $\alpha$ \\
\hline & Pro-IL-1 $\beta$ & \\
\hline & Entactin & Plasminogen \\
\hline & Fibrin, fibrinogen & $\alpha_{1}$-Proteinaz inhibitörleri \\
\hline & Fibronectin & \\
\hline & Gelatin & \\
\hline & Laminin & \\
\hline & Tenascin & \\
\hline & Vitronectin & \\
\hline
\end{tabular}

konjuge olabilir. LTC4, çoklu ilaca direnç ile ilişkili proteini taşıyıCı olarak kullanarak, hücre dışına göç eder, ekstrasellüler alanda LTD4 ve LTE4'e metabolize olabilir. Bu üç sisteinil lökotrien, yavaş ve uzun süreli düz kas kasıcı etkileri nedeni ile anaflaksinin yavaş reaksiyon veren maddeleri olarak adlandırılır. Bunlar postkapiller venüllerden plazma sızışını arttııılar, hücre yüzeyi adezyon molekül ekspresyonunu arttıırlar ve bronkokonstrüksiyona neden olurlar ${ }^{17}$.

\section{Histamin}

Histamin kapiller sızmayı arttıran bazofil ve mast hücrelerinden salınan vazoaktif bir amindir. Bazofillerden histamin salınımı bakteriyel formylmethionyl-leucyl-phenylalanine (f-MLP) parçaları, kompleman fragmanları C3a ve C5a, ve IgE tarafından uyarıı. Bunun etkisi ile ortaya çıkan vazodilatasyon klinikte ani ürtiker reaksiyonu olarak gözlenir. Astım ve sinovitte histamin üretilse bile histamin blokajının en bariz etkisi ürtikerde görülmektedir, diğer inflamatuvar hastlıklarda antihistaminlerin etkisi minimaldir. Mast hücre granüllerinden histamin salınımı için gerekli olan uyarı bazofillerle aynıdır, sadece bu hücre tipinde f-MLP reseptörleri yoktur. Histamin aynı zamanda lokal olarak üretilen LTB4 ve LTC4 ile de sinerji gösterir. Ayrıca histamin lökosit yuvarlanmasını, adezyonu ve ekstravazasyonunu $\operatorname{arttırır}^{18}$.

\section{Kininler}

Kininler vasodilatasyon, ödem ve düz kas kontraksiyonuna, C liflerinin uyarıması ile ağrı ve hiperaljeziye neden olur. Bunlar plazma ve periferik dokularda düşük ve yüksek molekül ağırlıklı kininojenlerden serin proteaz olan kallikreinin etkisi ile oluşurlar ${ }^{19}$. Kininojen yıkımının ana ürünleri bradikinin ve lizil-bradikinindir. Bu ürünler kininlerin birçok etkilerinden sorumludur ve yaygın olarak eksprese edilen B2 reseptörü için afiniteleri yüksektir. desArg-BK ve Lys-desArg-BK peptidleri karboxypeptidazlar tarafından üretilir ve kinin B1 reseptör alttipine bağlanır, bu normal dokularda eksprese edilmez fakat TLR ligand ve sitokinler tarafından upregüle edilir. Kinin B2 reseptörü hızla internalize ve desensitize edilirken B1 reseptörü yüksek oranda aktif kalır. Kinin etkileri, nitrik oksit, mast hücre kaynaklı ürünler ve IL-6, IL-8 gibi proinflamatuvar sitokinler gibi, inflamasyonun diğer mediatörlerinin sekonder üretimi ile ilişkilidir. Ayrıca kininler TNF stimulasyonu ile IL-1 üretimini arttıırlar ve fosfolipaz A2 ve araşidonik asit salınımı ile prostanoid üretimini artırabilirler ${ }^{19}$.

\section{Inflamasyonda doku hasarı}

\section{Reaktif oksijen ve nitrojen araürünleri}

Makrofajlar, nötrofiller ve diğer fagositik hücreler, patojenleri direkt olarak öldüren, fazla miktarda toksik reaktif oksijen araürünleri (ROls) ve reaktif nitrojen araürünleri (RNIs) oluştururlar. ROls ve RNIs aynı zamanda inflamatuvar genlerin ekspresyonunu regüle eden sinyal iletim molekülleri olarak görev yaparlar. Bu moleküllerin normal dokular üzerinde, DNA hasarı, membran lipidlerinin oksidasyonu ve proteinlerin nitrolizasyonu gibi zararlı etkileri vardır20.

Reaktif araürünlerin salınımı, LPS gibi mikrobial ürünler, IFN- $\gamma$ ve IL-8 gibi sitokinler ve $\mathrm{Fc}$ reseptörlerinin IgG ile bağlanması ile başlatılabilmektedir. Bu olaylar, membrana bağlı komplekse sitokrom C taşıyan Rac2 ve Rho-family guanosine triphosphatase (GTPase), gibi bazı sitozolik proteinlerin translokasyonuna neden olur ve ardından redükte nicotinamid adenin dinükleotide phosphate (NADPH) oxidaz aktive olur.2 NADPH oksidaz tarafından katalize edilen bu tepkime, hidrojen peroksit, hidroksil radikalleri ve anyonlar, hipokloröz asit ve kloraminlerin artışına neden olan süperoksit üretimine yol açar. Nitrik 
oxit sentazlar (NOS) L-arginin ve moleküler oxijeni L-sitrullin ve nitric oxid (NO)'e çevirirler. NOS un bilinen 3 izoformu vardır: nöronal NOS (ncNOS veya NOS1) ve endoteliyal hücre NOS (ecNOS veya NOS3) yapısal olarak eksprese edilirken, makrofaj NOS (macNOS, iNOS, veya NOS2) TNF- $\alpha$ ve IFN- $\gamma$ gibi inflamatuvar sitokinlerin yanısıra virus, bakteri, protozoa ve mantarlar, düşük oksijen basıncı ve düşük çevresel $\mathrm{pH}$ tarafından indüklenmektedir2. Prostaglandinlerle birlikte, NO nun NOS2 ve ROls in NADPH oksidaz tarafından üretilmesi makrofajların T hücre proliferasyonunu paradoksik olarak bozmasında esas faktördür. Bu olay inflamatuvar procesi kontrol ederek veya otoreaktif T hücrelerini yok ederek bazı enfeksiyon ve malignitelerde görülen immunsupresif durumdan kısmen sorumludur.

\section{Proteazlar}

ECM yıkımına neden olan enzimlerin üretimi, inflamasyonda doku yenilenmesinde önemli bir mekanizmadır. Matriksin rekonfigurasyonu hasarlı dokuları tamir eder, matriks bağımlı büyüme faktörleri ve sitokinleri salar, yeni kan damarları için dokuyu hazırlar ve yeni gelen hücrelerin tutunmaları için lokal ortamı hazırlar2.
Matriks metalloproteinazları (MMPs), ECM yenilenmesi ve degredasyonunda görev alan 20 den fazla ekstrasellüler endopeptidaz içeren bir ailedir ( Tablo 3 ). Bunlar pro-enzim olarak üretilir ve katalitik bölgenin ortaya çıkması için sınırlı proteoliz veya parsiyel denaturasyon gerektirir. Adlarını, aktivite için metal iyonlarına bağımlı olmaları ve yapısal ECM proteinlerini yıkmadaki etkilerinden almışlardır. MMP; hücre yüzey molekülleri ve diğer perisellüler nonmatrix proteinlerini parçalayıp hücre davranışlarını düzenleyeci etki gösterebilirler. Örneğin MMPs büyüme faktörleri ile ilişkili matriks proteinlerini yıkarak hücre büyümesini değiştirebilir. FGF ve TGF- $\beta$ 'nın aktivasyon durumunda, bu sitokinlerin depolanması için depo olarak görev yapan matriks moleküllerine karşı yüksek afiniteye sahiptir. Matriks proteolizi bazı büyüme faktörlerini salar ve bunları bazı hücre yüzey reseptörleri için hazır hale getirir. Ayrıca MMPs büyüme faktörlerini direk olarak parçalayarak aktif hale getirir. MMPs hücre-matriks veya hücrehücre reseptör bölgelerini değiştirerek hücre migrasyonunu etkilerler. Örneğin bir adezyon molekülü olan $\beta 4$ integrin MMP-7 ile parçalanır. MMP-3 ve MMP-7 E-cadherini sindirir ve sadece endotelial hücre

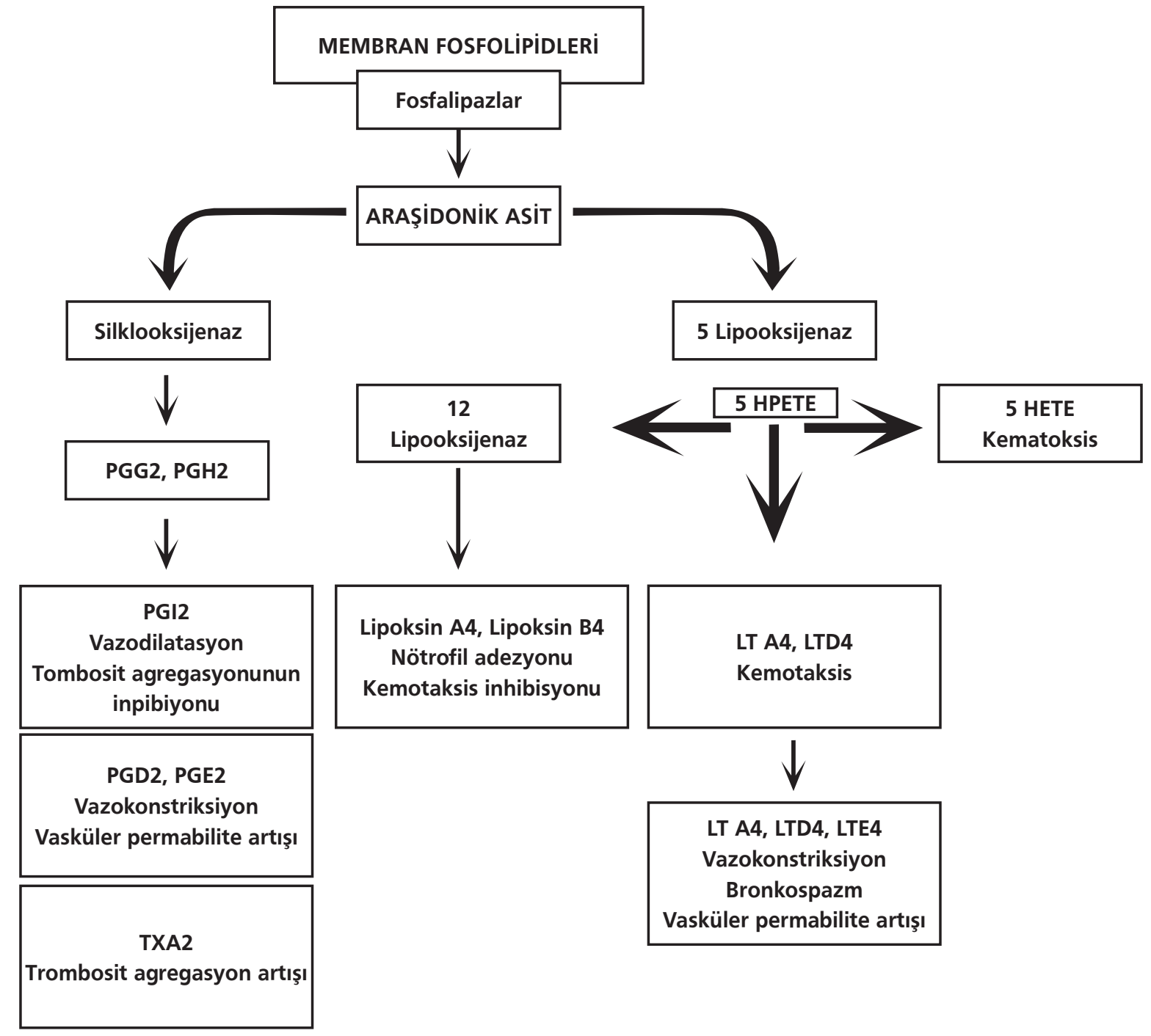

Şekil 1. Araşidonik asit metabolitleri 
bağlantılarını bozmakla kalmaz aynı zamanda hücre migrasyonunu da uyarır21. ECM yıkımı genellikle, kollajeni yıkan, kollajenazlar tarafından başlatılır. Denature kollajen daha sonra jelatinaz ve stromelisinler tarafından yıkılır. Kollajenazların aksine, stromelisinler geniş bir substrat spesifitesi gösterirler ve proteoglikan, fibronektin, laminin ve kartilaj proteinleri gibi bir çok ECM proteini üzerine etki ederler. Stromelisinler aynı zamanda, sınırlı proteoliz ile kollajenazı aktive ederek onarım sürecini de amplifiye ederler ${ }^{2}$. Serin ve sistein proteazlar gibi diğer bazı protaz grupları da matriks onarımında rol oynar. Tiripsin, kimotripsin ve elastaz gibi aktif serin proteazlar inflamasyon bölgesinde PMNL'ler tarafından yüksek miktarda salınır ve direkt olarak ECM'i parçalar yada salınan MMPs lerin proenzim formlarını aktive eder. Bir disintegrin ve metalloproteinaz olan ADAM ailesi sitokin reseptörlerinin ekstrasellüler parçasını ayırır. Bu ECM proteazları aggrecanase ailesinin 2 üyesini içerir. Aggrecanase 2'nin (ADAMTS5) osteartritte önemli rol oynadığı gösterilmiştir22.

\section{Doku tamiri ve inflamasyonun gerilemesi}

Inflamasyon normal bir fizyolojik yanıttır ama devam etmesine izin verilmesi halinde dokularda ciddi zedelenmelere neden olabilir. Bu nedenle inflamatuvar yanıt başlarken dengenin sağlanması için ilave mekanizmalar da devreye girmektedir. Mediatörler ve efektör hücrelerin kaldırılması veya devre dışı bırakılması ile akut inflamasyonun baskılanması konağa uygun büyüme faktörleri ve sitokinlerin salınarak hasarlı dokuların tamir edilmesine izin verir (Tablo 1). Bir enflamatuar yanıtın ilk başlangıcında rezolusyon bileşenleri hücresel yanıt (apoptoz ve nekroz), soluble mediatörler (örneğin, anti-inflamatuar sitokinler ve antioksidanlar gibi) ve direkt efektörlerden (örneğin, proteaz inhibitörleri gibi) oluşur².

Inflamatuvar hücrelerin ortamdan uzaklaştırılması

Inflamasyon bölgesindeki hücreler farklı mekanizmalarla buradan uzaklaştırılırlar23.

1) Hücre akışı kemotaktik faktör üretimi ve vasküler adezyon molekül ekspresyonunun baskılanması ile azaltılır.

2) Hücreler, özellikle lenfositler, dokudan ayrılarak lenfatikler aracılığı ile dolaşıma karışırlar.

3) Stres altındaki hücreler içeriklerini lokal çevreye salarak nekroza giderler.

4) Inflamasyon alanından hücrelerin temizlenmesindeki en önemli mekanizma apoptozistir2

Apoptozis, ökaryotik hücrelerde hücre ölümüne yol açan ve fagositler tarafından hızlı bir şekilde uzaklaştırıması için yüzey membranı işaretleyen, oldukça düzenli bir süreçtir. Bu temizleme süreci, nekroz ile hücre ölümünün aksine, inflamatuvar yanıt oluşturmaz24. PMN fagositlerin dokudaki ömürleri çok kısadır ve ölümünden sonra bu bölgede kalmaları ya da içeriklerinin mikroçevreye salınması zararlı olabilir. Lökositoklastik vaskülit gibi bazı patolojik durumlarda, bol nötrofil apoptozu histopatolojik incelemede kolayca görünür ve tanı için gerekli patolojik kriterlerden biridir. T lenfositler gibi diğer hücreler, konağa zarar vermemek için aktivasyon sonrası apoptoza giderler. Defektif apoptozis veya apoptotik hücrelerin sebat etmesi bile kronik inflamatuvar ve otoimmün hastalıklara katkıda bulunabilir2.

Hücre apoptozu hücresel mikroçevrede ROI'lerin yanı sıra FasL/ Fas ve TNF-ilişkili apoptoz indükleyen ligand (TRAIL) gibi çok sayıda ölüm reseptör yolakları aracılı̆ı̆ıla başlatılabilir. İnflamatuvar süreçte yaygın olarak üretilen bir araürün olan ROI'ler DNA yı hasarlayabilir. Eğer DNA hasarı fazla ise, sıkı regüle edilen tamir mekanizmaları tarafından tamir sonlandırıır ve programlanmış hücre ölümü başlar. Kronik inflamasyonda ROI'ler veya RNI'ler ile indüklenen mutasyon yükü zaman içinde birikir ve sonuçta önemli düzenleyici proteinlerde amino asit değişimlerine yol açabilir ve ülseratif kolitte gözlendiği gibi neoplastik hastalık gelişebilir. Apoptotik hücrelerin yada apoptotik hücre artıklarının uzaklaştırıması çok hızlıdır ve makrofajlar, fibroblastlar, epiteliyal ve endoteliyal hücreler, kas hücreleri ve dendritik hücreler tarafından sağlanır. Apoptotik hücrelerin tanınmasında ve bunların çevrelenmesinde kullanılan yüzey reseptörleri integrinler (örneğin $\alpha \vee \beta 3$ ), lektinler, çöpçü reseptörler, adenosin trifosphate (ATP)-bağlayan kaset taşıyıCı 1, LPS reseptörü, CD14, ve compleman reseptörü CR3 ve CR4'dür23-25. Bununla birlikte, bu membran moleküllerinin bazıları hem pro-inflamatuar hem de apoptotik yolaklarda kullanılabilir, bu ayrım farklı ligandlar ve aksesuar moleküller aracılığı ile sağlanmaktadır. Apoptotik hücreler, fagositler üzerindeki reseptörler ile etkileşime giren bir dizi membran-ilişkili moleküler paternler sergilerler. Apoptotik hücreler ve fagositler arasındaki etkileşimin ayrıntıları, kısmen anlaşılmıştır. Apoptotik hücrelerin genel bir özelliği fosfatidilserinin dış presentasyonu ile fosfolipid asimetrisininin kaybıdır. Dışsallaşmış fosfatidilserin fagositozu tetiklemek için yeterli olabilir, ancak diğer apoptotik hücre yüzey yapıları da bulunmaktadır23-25.

Iyileşme sürecinde bazı hücreler yok edilirken, bazıları da artış gösterebilir. Mezenkimal hücreler, özellikle fibroblastlar, çoğalarak fibrotik skar oluşturabilirler. Örneğin PDGF ve TGF- $\beta$ gibi lokal olarak üretilen büyüme faktörleri stromal hücrelerde DNA sentezini indükler. Ayrıca, dokuda var olan yada periferik kandan dokuya gelen pluripotent mezenkimal kök hücreler, adiposit, kondrosit, kemik hücreleri ya da diğer farklılaşmış stromal hücreler gibi organ-spesifik hücrelere dönüşebilirler26.

\section{Soluble mediatörler}

\section{Anti-inflamatuvar sitokinler}

Anti-inflamatuar sitokinler inflamasyon bölgesine gelen yada burada zaten var olan hücreler tarafından salınır. Örneğin TGF- $\beta$ ve IL-10 makrofajlar, interstisyel fibroblastlar veya T-hücreleri tarafından üretilir. IL-4, IL-10 ve IL-13 gibi bazı T-hücre sitokinleri, IL-1 veya TNF ile uyarılmış hücrelerden, MMP ekspresyonunu baskılarlar. TGF- $\beta$, fibroblast proliferasyonuna ek olarak, kollajenaz üretimini baskılar, kollajen depolanmasını arttııı ve metaloproteinazların doku inhibitörlerinin (TIMP) üretimini uyararak MMP aktivitesini azaltır. Fibrozisin önemli bir bulgu olduğu hastalıklarda tamir fazı anormaldir. Örneğin, skleroderma diffüz fibrozis ile seyreder ve artmış ECM ve yüksek TGF- $\beta$ seviyeleri ile birliktedir26,27.

Çöpçü sitokin (decoy) reseptörleri de inflamatuvar yanıtı azaltır. Reseptörler aynı zamanda proteolitik bölünme sonrasında hücre yüzeyinden dökülerek sitokinleri absorbe edebilir ve böylece bunların hücre yüzeyindeki fonksiyonel reseptörlerine bağlanmasını engeller. Bu sitokin inhibitörleri, septik şokta başlangıçtaki masif TNF ve IL-1 üretimini takiben endotoksinlerin soluble reseptör üretimini indüklediği gibi, kontrolsüz inflamasyonu önlemek için koordinasyon sağlamak üzere salınırlar. IL-18'i bağlayan ve bir Ig süperailesi ile ilişkili reseptör olan IL-18 bağlayıcı protein (IL-18BP) gibi diğer sitokin bağlayıcı proteinler de düzenleyici mekanizmalar olarak devreye girer.

Pro-inflamatuar sitokin olan IL-1'in sıkı bir kontrolü için iki ayrı mekanizma vardır. Tip II IL-1R olarak bilinen formun, IL-1 aktivitesini nötralize eden hücre membranı ve çözünür formları bulunmaktadır. Ayrıca, doğal bir IL-1 antagonisti olan IL-1Ra işlevsel IL-1 reseptörlerine 
bağlanır ve IL-1 $\alpha$ veya IL-1 $\beta$ ile rekabet eder. Bununla birlikte, IL-1Ra ortamdaki IL-1 in biyolojik fonksiyonlarını bloke eder ve hücrelere sinyal iletmez. IL-1 ve IL-1Ra nın üretim dengesi farklı faktörlere bağlıdır. Örneğin, monositler daha fazla IL-1 üretirken olgun makrofajlar IL-1Ra üretirler.

\section{Prostanoidler ve siklooksijenaz}

COX2 nin indüklediği pro-inflamatuvar mediatörler erken dönemde ortaya çıkar ve inflamatuar yanıta katkıda bulunur. Bu düzenleme siklopentenon prostaglandin (CYPG) oluşumu ile ortaya çıkabilir. Prostanoidler peroksizom proliferatör ile aktive edilen reseptörler (PPAR'ler) için ligand oluştururlar. Retinoid $X$ reseptörü ile birlikte heterodimerler olarak DNA'ya bağlanan 3 ana PPAR reseptörleri (PPAR $\alpha, \operatorname{PPAR} \beta$ / $\delta$ ve PPAR $\gamma$ ) vardır. CYPG ile PPAR $\gamma$ aktivasyonu, aktivatör protein 1 'in (AP-1) baskılanması ve makrofajlarda STAT transkripsiyonu ile ilişkilidir. Doğal ve sentetik PPAR $\gamma$ agonistlerinin etkinliği çeşitli iskemi-reperfüzyon hasarı, artrit ve enflamatuvar hava yolu hastalıklarında gösterilmiştir.

\section{Direkt efektörlerin inhibisyonu Antioxidanlar}

Toksik ara ürünleri inaktive eden ve normal dokuları koruyan antioksidan enzimler katalaz ve süperoksit dismutazdır. Katalaz, peroksizom enzimdir ve hidrojen peroksitin su ve oksijene dönüşümünü katalize eder. Süperoksit dismutazlar (SOD) süperoksitlerin hidrojen peroksite dönüşümünü katalizler, bu da daha sonra katalaz veya glutation peroksidaz ile ortamdan uzaklaştırılır. Glutatyon peroksidaz ve glutatyon redüktaz redoks dengesini sağlayan ve toksik metabolitleri uzaklaştıran ek mekanizmalardır. Glutatyon gibi hücre içi antioksidanların yetersiz üretimi lenfosit yanıtlarını bastırarak kusurlu T hücre reseptör sinyal iletimine ve romatoid artritte $T$ hücrelerinin körelmiş immunitesinden sorumludur. Serbest radikallerin çevredeki moleküller ile etkileşimleri kendi kendine yayılan zincir reaksiyonu ile ikincil radikal türevleri oluşturabilir. Zincir kıran antioksidanlar bir elektron alan yada veren küçük moleküllerdir, bu şekilde radikal ile kararlı bir yan ürün oluşturur. Bu antioksidan moleküller ya sıvı faz (C vitamini, albümin, indirgenmiş glutatyon) veya lipid faz (vitamin E, ubikinol-10, karotenoidler ve flavonoidler) olarak sınıflandırılır. Ayrıca, metal-bağlayıcı proteinler (seruloplazmin, ferritin, transferrin ve laktoferrin) kompleks katyonik demir ve bakırı sekestre ederek antioksidan olarak görev yapar ve böylece hidroksil radikallerin yayılmasını inhibe eder.

\section{Proteaz İnhibitörleri}

Proteaz inhibitörleri endojen proteazların fonksiyonunu düzenler ve çevre dokularda ortaya çıkabilecek hasarı azaltır. Bu proteinler, aktif bölge inhibitörleri ve $\alpha 2$-makroglobulin ( $\alpha 2 \mathrm{M}$ ) olmak üzere iki gruptur. Proteaz inhibitörlerinin ikincisi proteazı $\alpha 2 \mathrm{M}$ zincirine kovalent bağlar ve böylece substrat erişimini bloke eder. $\alpha 2 \mathrm{M}$, proteazların bütün alt gruplarına bağlanır ve kovalent bağ oluştuktan sonra bunu reseptör aracılı endositoz yoluyla hücrelere taşır ve sonrasında enzimatik inaktivasyon olur. Serin proteaz inhibitörleri (SERPiNs) ailesi, daha önce proteaz inhibitörü olarak bilinen ailenin en kalabalık üyesidir ve pıhtı rezolusyonunda ve inflamasyonda önemli rol oynar, bunlar antitrombin III, plazminojen aktivatör inhibitörü 1 ve 2, $\alpha 2$-antiplazmin, $\alpha$-1 antitripsin, ve kallistatin dir2.

Metalloproteinaz doku inhibitörleri (TIMP) ailesi birçok MMP fonksiyonunu baskılar. TIMP, aktive olan MMP'ye bağlanarak bunların katalitik bölgelerini geri dönüşümsüz olarak baskılar. TIMP ve MMP arasındaki dengenin bozulması sonucu ortaya çıkan durumlara artritteki kartilaj kaybı ve tümör metastazları örnek verilebilir. Destruktif artrit formlarında görülen TIMP-MMP dengesizliği MMP'lerin artmış ekspresyonu ve proteaz inhibitörlerinin sınırlı üretiminden kaynaklanmaktadır. IL-1 ve TNF- $\alpha$, MMP leri indüklerken, IL-6, TGF- $\beta$ ve çeşitli büyüme faktörleri MMP leri inhibe eder ve TIMP seviyelerini arttırır. Bu nedenle, sitokin profili remodelingde önemli etkiye sahiptir. Pro-inflamatuar sitokinlerin baskın olduğu durumlarda, denge matriks yıkımından yanadır, pro-inflamatuar sitokin inhibitörleri ve büyüme faktörleri varlığında matriks protein üretimi artar ve MMP'ler TIMP tarafından inhibe edilir.

\section{Sonuç}

Normalde organizmanın yararına çalışan inflamatuvar süreç eğer yeterli işlemezse enfeksiyonlara yatkınlık artar, çünkü inflamatuvar süreç savunmanın erken basamaklarında önemli rol oynayan doğal immun sistemin önemli bir bileşenidir. Ayrıca inflamasyon hasarlanmış dokuIarın uzaklaştırılmasında ve tamir sürecinde önemli rol oynadığı için yara iyileşmesi de gecikir. Diğer taraftan inflamatuvar yanıtın aşırı ya da kontrolsüz olması bir çok hastalığın ortaya çıkmasına neden olmaktadır. Çevremizde karşılaştığımız birçok allerjene anormal yanıt verilmesi sonucu allerji, normalde tolere edilebilen self antijenlere yanıt verilmesi durumunda ise otoimmun hastalıklar ortaya çıkmaktadır. Kronik inflamasyon ve fibrozis birçok enfeksiyöz ve metabolik hastalıkların uzamış seyrinden sorumludur.

\section{Kaynaklar}

1. Ferrero-Miliani L, Nielsen $\mathrm{OH}$, Andersen PS, Girardin SE: Chronic inflammation: importance of NOD2 and NALP3 in interleukin-1beta generation. Clin Exp Immunol 2007;147:227-35.

2. Goldman L, Schafer Al: "Mechanisms of inflammation and tissue repair" Cecil Medicine: Expert Consult Premium Edition 24th Saunders (Elsevier) 2012;1604-7.

3. Kumar V. Abbas AK. Aster JC. "Inflammation and repair" Robbins Basic Pathology ( $9^{\text {th }}$ edition) Saunders (Elsevier) 2013;43:1781-5.

4. Abbas A.B.; Lichtman A.H. "Innate Immunity". Basic Immunology. Functions and disorders of the immune system ( $3^{\text {rd }}$ ed.). Saunders (Elsevier) 2009;978:4688-2.

5. Martinon F, Mayor A, Tschopp J,et al : The inflammasomes: guardians of the body. Annu Rev Immunol 2009;27:229-265.

6. Bauernfeind F, Ablasser A, Bartok E, Kim S, Schmid-Burgk J, Cavlar T, Hornung V: Inflammasomes: current understanding and open questions. Cell Mol Life Sci 2011;68:765-83.

7. Barrientos S, Stojadinovic O, Golinko MS, Brem H, Tomic-Canic M Growth factors and cytokines in wound healing. Wound Repair Regen 2008;16:585601.

8. Kolaczkowska E, Kubes P: Neutrophil recruitment and function in health and inflammation. Nat Rev Immunol 2013;13:159-75.

9. Davis DM: Mechanisms and functions for the duration of intercellular contacts made by lymphocytes. Nat Rev Immunol 2009;9:543-555.

10. Hassoun PM, Mouthon L, Barberà JA, Inflammation, growth factors, and pulmonary vascular remodeling.J Am Coll Cardiol 2009;54(1 Suppl):10-9.

11. Golias C, Tsoutsi E, Matziridis A, Makridis P, Batistatou A, Charalabopoulos $\mathrm{K}$ : Leukocyte and endothelial cell adhesion molecules in inflammation focusing on inflammatory heart disease.In Vivo 2007;21:757-69.

12. McFadden J, Fry L, Powles AV, Kimber I. Concepts in psoriasis: psoriasis and the extracellular matrix. Br J Dermatol 2012;167:980-6.

13. Keating SM, Jacobs ES, Norris PJ. Soluble mediators of inflammation in HIV and their implications for therapeutics and vaccine development.Cytokine Growth Factor Rev 2012;23:193-206. 
14. Mills KH, Dungan LS, Jones SA, Harris J.The role of inflammasome-derived IL-1 in driving IL-17 responses. J Leukoc Biol 2013;93:489-97.

15. Ariza ME, Williams MV, Wong HK. Targeting IL-17 in psoriasis: from cutaneous immunobiology to clinical application. Clin Immunol 2013;146:131-9.

16. Hirata T, Narumiya S.Prostanoids as regulators of innate and adaptive immunity. Adv Immunol 2012;116:143-74.

17. Di Gennaro A, Haeggström JZ. The leukotrienes: immune-modulating lipid mediators of disease. Adv Immunol 2012;116:51-92.

18. Amin K. The role of mast cells in allergic inflammation. Respir Med 2012;106:9-14.

19. Maurer M, Bader M, Bas M, et al. New topics in bradykinin research.Allergy 2011;66:1397-406.

20. Zhu H, Li YR. Oxidative stress and redox signaling mechanisms of inflammatory bowel disease: updated experimental and clinical evidence.Exp Biol Med (Maywood) 2012;237:474-80.

21. Knapinska A, Fields GB. Chemical biology for understanding matrix metalloproteinase function. Chembiochem 2012;13:2002-20
22. Fosang AJ, Beier F. Emerging Frontiers in cartilage and chondrocyte biology. Best Pract Res Clin Rheumatol 2011;25:751-66.

23. Serhan CN.Controlling the resolution of acute inflammation: a new genus of dual anti-inflammatory and proresolving mediators. J Periodontol 2008;79(Suppl 8):1520-6.

24. Yuan Wei, Yan Jinchuan, Liang Yi, Wu Jun, Wang Zhongqun, Wang Cuiping antiapoptotic and Proapoptotic Signaling of Cyclophilin A in Endothelial Cells June 2013;36:567-572.

25. Blank M, Shiloh Y: Programs for cell death: apoptosis is only one way to go. Cell Cycle 2007;6:686-695.

26. Lee, Kaluri, 2010Lee SB, Kaluri R: Mechanistic connection between inflammation and fibrosis. Kidney Int 2010;78:22-26.

27. Wang et al, 2011Wang J, Hori K, Ding J,et al : Toll-like receptors expressed by dermal fibroblasts contribute to hypertrophic scarring. J Cell Physiol 2011;226:1265-1273. 